\section{Kronisk utmattelsessyndrom og evolusjonær tilpasning}

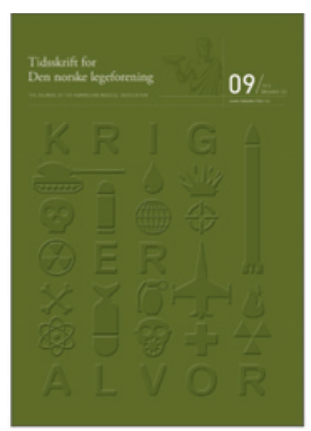

I Tidsskriftet nr. 9/2012 skriver Iver Mysterud at han ikke kan se hvordan kronisk utmattelsessyndrom kan ha vært adaptivt $i$ et fortidsmiljø der overlevelse var avhengig av jakt og sanking. Mysterud finner det vanskelig å forstå hvordan en langvarig tilstand preget av alvorlige plager kan øke egnethet i forhistoriske kontekster som krevde fysisk og mental årvåkenhet (1).

Jeg er usikker på hvor relevant det er å ta utgangpunkt $\mathrm{i}$ jeger- og sankersamfunn i analyser av menneskelig psykologi og atferd. Moderne mennesker er produkter av pågående evolusjon i stadig mer avanserte jordbrukssamfunn - ikke direkte etterkommere av nomader (2). Men uavhengig av hvilken del av menneskets utviklingshistorie man tar utgangpunkt $i$, har Mysterud rett $i$ at det har vært viktig med årvåkenhet og overskudd. For å forstå hvordan kronisk utmattelsessyndrom kan være en tilpasning må vi derfor ta med $\mathrm{i}$ betraktningen et fundamentalt premiss for menneskelig eksistens - at suksess i både overlevelse og reproduksjon ikke er et spørsmål om individet $\mathrm{i}$ ensom majestet, men heller er fortellingen om gjensidig avhengighet.

Mennesker overlever og reproduserer i tett sammenføyde grupper der suksess er knyttet til at individer fremmer sine egne interesser - reproduktive så vel som andre - gjennom forpliktende samarbeidsrelasjoner. Mennesket er - for å sitere Matt Ridley «a groupish species» (3). Vi bruker gruppen for å fremme egen overlevelse og reproduktive suksess.

Mennesker som over lang tid har bidratt til gruppens overlevelse og opptrådt lojalt og støttende overfor sine egne, blir ikke overlatt til seg selv dersom de blir syke eller opplever funksjonsfall, slik som kronisk utmattelsessyndrom. Teorien om at kronisk utmattelsessyndrom er en adaptiv barriere mot kollaps hviler slik ikke på at mennesker står alene i en farlig verden. Forutsetningen for at kronisk utmattelsessyndrom er en tilpasning, er at personer med omsorgsansvar blir vernet av gruppen de tilhører, selv når de er inne i en langvarig og plagsom utmattelse, og på denne måten senere kan verne egen (og gruppens) reproduktiv suksess over tid.

Premisset for å forstå kronisk utmattelsessyndrom som en adaptiv barriere mot kollaps er altså at mennesker kan overleve i lange perioder uten optimalt overskudd og årvåkenhet fordi vi lever i gjensidig forpliktende og beskyttende grupper. Ingen primære omsorgsgivere vernet sine barns overlevelse atskilt fra sine respektive grupper. Det at symptomene er for alvorlige og at tilstanden for langvarig til at kronisk utmattelsessyndrom kan være en tilpasning, er derfor bare en tilsynelatende selvmotsigelse (i.e. et paradoks) og falsifiserer ikke teorien som jeg fremsatte i Tidsskriftet nr. 4/2012 (4).

\section{Rune Karlson}

rune.karlson@ppt.rogfk.no

Stavanger

Rune Karlson (f. 1971) er spesialist i klinisk psykologi. Han arbeider ved Pedagogisk-psykologisk tjeneste for videregående skoler i Rogaland og er i tillegg privatpraktiserende psykolog i Stavanger.

Ingen oppgitte interessekonflikter.

\section{Litteratur}

1. Mysterud I. Kronisk utmattelsessyndrom og evolusjon. Tidsskr Nor Legeforen 2012; 132: 1060

2. Diamond J. Guns, germs and steel: a short history of everybody for the last 13,000 years. London: Vintage, 1998

3. Ridley M. The origins of virtue: human instincts and the evolution of cooperation. London: Penguin Books, 1996.

4. Karlson R. En evolusjonær forståelse av kronisk utmattelsessyndrom. Tidsskr Nor Legeforen 2012; 132: 400-1.

\section{Omfattende kritikk av Litauen-studiene?}

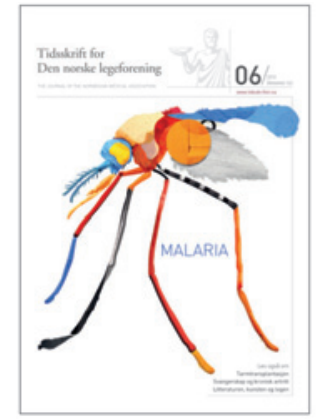

I Tidsskriftet nr. 6/2012 kommer advokat Stein Chr. Hexeberg, som sin kollega Sven Knagenhjelm i 2010, med påstanden om at Litauen-studiene (der man undersøkte følgetilstander etter nakkesleng) skal ha fått «omfattende kritik» $(1,2)$. Det kan bare gjentas at det siden publiseringen av den prospektive studien i 1999 (3) ikke er publisert et eneste detaljert kritisk innlegg $i$ et internasjonal vitenskapelig tidsskrift mot dette arbeid. Utenfor disse fora og det ene arbeidet Hexeberg siterer,

finnes ifølge Knagenhjelm (4) kritikk også i en svensk bok (5). Når man ser nærmere på denne kritikken finner man en usedvanlig forvrengt fremstilling av Litauen-studien. Det er meget vanskelig å få tak i boken fordi den ikke lenger er i handelen og kun er tilgjengelig på to svenske biblioteker. Knagenhjelm gir ingen detaljer av kritikken, og alt i alt vil dette kunne villede aktører i retten til å tro at det er kommet ny og saklig kritikk. Bare én setning i metodebeskrivelsen i kritikken gjengir noe fra artikkelen. Den resterende metodefremstilling er fullstendig irrelevant. Man har heller ikke brydd seg om å referere det viktigste resultatet fra artikkelen: «Initial pain was reported by $47 \%$ of accident victims; $10 \%$ had neck pain alone, $18 \%$ had neck pain together with headache, and $19 \%$ had headache alone. The median duration of the initial neck pain was 3 days and maximal duration 17 days. The median duration of headache was 4.5 hours and the maximum duration was 20 days.» I stedet går man direkte etter metodebeskrivelsen over til følgende bemerkning: «Slutssatsen även i denne artikel är att symptom efter akut whiplashskada är självbegrensande och kortvariga.» Deretter påstås uten tallmessig begrunnelse at man for statistisk holdbarhet av studien hadde trengt hele 2600 påkjørselsofre og 2600 kontrollpersoner.

En kreativ oppskrift for kritikk av studier man ikke liker er som følger: Man lager et vrengebilde ved å deformere og redusere metodebeskrivelsen i negativ retning. Så lar man være å gjengi sentrale resultater (ingen av 210 ofre etter påkjørselsulykker med ulykkesrelaterte langstidsfølger; her trengs selvfølgelig ingen statistikk), men bygger disse inn i en konklusjon som virker å være tatt ut av det blå. Til slutt fremsetter man uten nærmere begrunnelse krav om hvor mange ulykkesofre og kontrollpersoner man burde ha hatt med i studien.

Er det kritikk av denne kvalitet, publisert i en svensk bok under «Studentlitteratur», som skal være veiledende for avgjørelser i norsk høyesterett (1)?

\section{Harald Schrader}

harald.schrader@ntnu.no

Institutt for nevromedisin

Norges teknisk-naturvitenskapelige universitet

Harald Schrader (f. 1944) er spesialist i nevrologi.

Ingen oppgitte interessekonflikter.

\section{Litteratur}

1. Hexeberg SC. Sakkyndighet i Høyesterett. Tidsskr Nor Legeforen 2012; 132: 618.

2. Knagenhjelm S. Bløtdelsskader etter lavhastighetskollisjoner. Tidsskr Nor Legeforen 2010: 130: 1908-9

3. Obelieniene D, Schrader H, Bovim G et al. Pain after whiplash: a prospective controlled inception cohort study. J Neurol Neurosurg Psychiatry 1999; 66 279-83.

4. Knagenhjelm S. Mer om nakkesleng. Tidsskr Nor Legeforen 2010; 130: 2449-50.

5. Nygren $\AA$, Magnusson S, Grant G. red. Nackskador efter bilolyckor. Lund: Studentlitteratur, 2000: 96 